\title{
Clinical evaluation and classification of patients with temporomandibular disorders using 'Diagnostic Criteria for Temporomandibular Disorders'
}

\author{
Cansu Alpaslan iD , ${ }^{1}$ Deniz Yaman iD ${ }^{2 *}$ \\ ${ }^{1}$ Department of Oral and Maxillofacial Surgery, Faculty of \\ Dentistry, Gazi University, Ankara, ${ }^{2}$ Department of Oral and \\ Maxillofacial Surgery, Faculty of Dentistry, Bolu Abant Izzet \\ Baysal University, Bolu, Turkey
}

\begin{abstract}
ObJective: The aim of the study was to evaluate the frequency of subgroups in a clinical setting of the patients with temporomandibular disorders (TMD) using 'Diagnostic Criteria for Temporomandibular Disorders (DC/TMD)'.

Materials and Method: A total of 128 patients with TMD (92 females and 36 males, mean age $33.5 \pm 8.28$ ) were involved in the study. DC/TMD Axis I diagnosis criteria was used for the clinical examination of pain disorders and temporomandibular joint (TMJ) disorders. Also, in DC/ TMD Axis I, The TMD Pain Screener, focusing on pain within the last 30 days, was used. In DC/TMD Axis II evaluation, the Jaw Functional Limitation Scale-8 (JFLS-8) was preferred to detect symptom severity and functional limitations. The data analysis was conducted by using the Chi-square, Kruskal Wallis test, and the Bonferroni correction for the Mann-Whitney $\mathrm{U}$ test.
\end{abstract}

Results: Out of 128 patients, 120 patients (93.75\%) had TMJ disorders that were accompanied by muscle pain disorders. The effect of gender and age on TMJ/muscle pain disorders was not significant (TMJ disorders; $p=0.123$, $p=0.263$; Muscle pain disorders; $p=0.145, p=0.100$, respectively). According to JFLS-8, the limitation in mastication (item 1 and 2) and joint mobility (item 4) were major complaints in the group of patients with 'disc displacement without reduction with limited opening' compared to the other TMJ disorders $(p=0.001, p=0.004, p=0.007, p<0.008)$.

Conclusion: DC/TMD Axis I is a significant reference to clinicians in the diagnosis and evaluation of TMD. In DC/ TMD Axis II, JFLS-8 is an efficient instrument for the measurement of functional limitation associated with temporomandibular disorders.

Received: May 19, 2019; Accepted: December 12, 2019

*Corresponding author: Dr. Deniz Yaman, Bolu Abant İzzet Baysal University, Faculty of Dentistry, Bolu, Turkey;

E-mail: yamand896@gmail.com
KEYWORDS: Temporomandibular joint disc temporomandibular joint disorders; temporomandibular joint dysfunction syndrome

Citation: Alpaslan C, Yaman D. Clinical evaluation and classification of patients with temporomandibular disorders using 'Diagnostic Criteria for Temporomandibular Disorders'. Acta Odontol Turc 2020;37(1):1-6

EdıтoR: Zühre Akarslan, Gazi University, Ankara, Turkey

Copyright: () 2020 Cansu Alpaslan and Deniz Yaman. This work is licensed under a Creative Commons Attribution License. Unrestricted use, distribution and reproduction in any medium is permitted provided the original author and source are credited.

Funding: None declared.

CONFLICT OF INTEREST: The authors declare no conflict of interest related to this study.

\section{INTRODUCTION}

Temporomandibular disorders affecting either temporomandibular joint (TMJ), masticatory muscles and/or associated structures present with various symptoms. The most common symptoms are pain, joint noises, and mandibular dysfunction, which all affected the patient's quality of life. Temporomandibular disorder does not always involve only one structure and patients may present overlapping signs and symptoms. ${ }^{1-3} \mathrm{~A}$ correct diagnosis is crucial for an appropriate understanding of the patient's condition and for an accurate determination of treatment. ${ }^{4}$

The Diagnostic Criteria for Temporomandibular Disorders (DC/TMD) was developed by the International Network for Orofacial Pain and Related Disorders Methodology (INFORM). ${ }^{5}$ It is the most recent evidence-based classification system for TMDs in two axes, for clinical and research purposes. ${ }^{6} \mathrm{DC} / \mathrm{TMD}$ Axis I was used for the clinical examination and for the diagnosis of pain disorders (myalgia, myofascial pain with referral, arthralgia, and headaches attributed to TMD) or temporomandibular joint disorders (disc displacements with or without reduction, subluxation, and degenerative joint disease). DC/TMD Axis II screening 
tools assess pain intensity, pain disability, jaw functioning, and psychosocial distress. ${ }^{5}$ Acceptable sensitivity and specificity for accurate diagnosis were observed both in pain disorders (sensitivity $\geq 0.86$, specificity $\geq 0.98$ ) and temporomandibular joint disorders (sensitivity of 0.80 and specificity of 0.97$).^{5}$

The TMD Pain Screener is a simple and valid selfreport instrument and it is part of the DC/TMD Axis I protocol. It is developed for screening pain disorders within the last 30 days with sensitivity and specificity $\geq 0.95 .^{3,7}$ It consists of six items that evaluate the pain stimulated by function, movement, or parafunction. It also focuses on the identification of people with painful TMJ and headache. ${ }^{5,7}$ However, the DC/TMD Axis Il focuses on the detection of pain-relevant psychosocial and behavioral functioning. ${ }^{5}$ This part has five, simple self-reported screening instruments. ${ }^{5}$ The Jaw Functional Limitation Scale-8 (JFLS-8) is one of the five recommended by the Axis II self-report screening instrument, and it evaluates the limitations while chewing, opening the mouth, and making verbal and emotional expression. ${ }^{8,9}$ In this scale (JFLS-8), items one, two, and three assess the effectiveness of chewing while item four expresses the restriction in the mouth opening and jaw mobility. Finally, items five, six, seven, and eight evaluate the limitation on verbal and emotional communication. ${ }^{9}$

The aim of this study is to evaluate the frequency of subgroups of TMD according to DC/TMD Axis I. The other goal of this study is to determine the pain-relevant psychosocial and behavioral limitation with JFLS-8 which is one of the DC/TMD Axis II instruments.

\section{Materials AND Method}

One hundred twenty-eight patients (92 females and 36 males) aged 18 to 50 years (mean age: $33.5 \pm$ 8.28) with symptoms of temporomandibular disorders (the feeling of muscular tension or stiffness during the day, masseter and/or temporal muscle and TMJ pain, restricted mouth opening, and TMJ noises while jaw movement) participated in this study. Research was approved by the Ethics Committee of the Gazi University, Ankara (No: 25901600-217), and all participants signed a consent form prior to the start of the study. The study was carried out between April and October 2016. Each participant underwent a detailed and standardized clinical examination and was given a Diagnostic Criteria for Temporomandibular Disorders (DC/TMD) Axis I assessment. According to DC/TMD Axis I, the incisal relationship of each participant, the presence of deviation or deflection when opening the mouth, the maximum amount of mouth opening, the amount of lateral and protrusive jaw movement, the presence of TMJ sounds during opening and closing of the jaw, and the presence of pain in the masticatory muscles during palpation were examined and subgroups of TMD was made according to the results obtained. In addition to clinical examination according to DC/TMD, TMJ was evaluated bilaterally in existing panoramic radiograph of all patients. Each examination was conducted by the same trained two oral and maxillofacial surgeons.

The TMD Pain Screener, which is part of the symptom questionnaire for the DC/TMD Axis I, was used to investigate the presence or absence of pain in the jaw or temple area and pain or stiffness in the jaw on awakening within the last 30 days. In addition, the participants were also asked about the factors that could change the severity of pain (such as chewing hard or tough food, opening the mouth, moving the jaw forward or to the side, holding teeth together, clenching, grinding, chewing gum, talking, kissing, and yawning).

Jaw Functional Limitation Scale-8 (JFLS-8) was used in DC/TMD Axis II section in this study. JFLS-8 is aimed to evaluate functional limitation of the jaw. The restriction due to TMD is indicated in eight items and these include changes in jaw mobility (item four), mastication (items 1-3), and verbal and emotional expression (items 5-8):

Item 1: Chewing though food

Item 2: Chewing chicken (e.g. prepared in oven)

Item 3: Eating soft food requiring no chewing

Item 4: Opening wide enough to drink from a cup

Item 5: Swallowing

Item 6: Yawning

Item 7: Talking

Item 8: Smiling

The participants were asked to determine the restriction levels for the eight items mentioned in this scale during the last month. They were asked to score between 0 and 10 according to the severity of the restriction. If the participant had completely avoided activity due to pain, he/she was informed that he/she should score this item with 10 points. Results were recorded for evaluation and scores of JFLS-8 were evaluated in four groups to facilitate the statistical analysis: response 0 , responses 1-3, responses 4-6, and responses 7-10.

\section{Statistical analysis}

The effect of gender and age variables on TMJ and Muscle Pain Disorders in patients with different DC/TMD diagnoses was compared by means of a Chi-square test. The non-parametric Kruskal Wallis test was used due to non-normally distributed JFLS-8 scores. Following the Kruskal-Wallis test, the Bonferroni correction for the Mann-Whitney $U$ test was used to detect specific symptoms that differed among other subgroups of TMD. All statistical procedures were evaluated using Statistical Package for Social Science (SPSS Inc, Chicago, IL), version 21.0 and MS-Excel 2007 (Microsoft Corp., Redmond, WA, USA). 
Table 1. Number of patients (n) with 'TMJ Disorders' and 'Muscle Pain Disorders' according to DC/TMD Axis I

\begin{tabular}{|c|c|c|c|c|c|c|c|c|}
\hline & & \multicolumn{7}{|c|}{ TMJ Disorders } \\
\hline & & 孚 & $\begin{array}{l}\frac{1}{3} \\
\frac{1}{3} \\
\text { on } \\
0\end{array}$ & 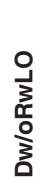 & 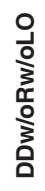 & 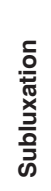 & 음 & 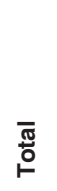 \\
\hline \multirow{3}{*}{$\begin{array}{l}\text { Muscle pain } \\
\text { disorders }\end{array}$} & No muscle pain & 12 & 1 & 8 & 1 & 1 & 3 & 26 \\
\hline & Myalgia & 30 & 4 & 5 & 1 & 1 & 5 & 46 \\
\hline & $\begin{array}{l}\text { Myofascial pain with } \\
\text { referral }\end{array}$ & 26 & 5 & 16 & 1 & 8 & 0 & 56 \\
\hline Total & & 68 & 10 & 29 & 3 & 10 & 8 & 128 \\
\hline
\end{tabular}

DDwR: Disc displacement with reduction, DDwRwIL: Disc displacement with reduction with intermittent locking,

DDw/oRwLO: Disc displacement without reduction with limited opening,

DDw/oRw/oLO: Disc displacement without reduction without limited opening, DD: Degenerative diseases

\section{Results}

A total of 128 patients with TMD (71.9\% females, 25.1 $\%$ males; age range: $18-50$ years; mean age: $33.5 \pm$ 8.28 years) were included in this study and the collected data was analyzed. The results from the TMD Pain Screener showed that 12 patients $(9.4 \%)$ had no pain in the jaw or temple area on either side, whereas 116 patients $(90.6 \%)$ had intermittent or continuous pain during the last 30 days. In the study, 97 patients $(75.8 \%)$ reported pain or stiffness in their jaws on awakening. Pain in the jaw or temple area on either side had worsened in the last 30 days by chewing hard or tough food (78.1\%), opening the mouth or moving the jaw forward or to the side $(75.8 \%)$, holding teeth together, clenching, grinding, chewing gum $(78.1 \%)$ and by activities like talking, kissing, yawning (82\%).
The result of the question of whether the patients had any headaches that included the temple areas of their head in the last 30 days was assessed. Headaches in the temple area were reported by 53 patients (41.4\%), consisting of 48 females and five males. The effect of gender on the presence of a headache was analyzed by Pearson's chi-square test. Those who reported headaches including the temple area were mostly females and this relation was found to be significant (the correlation coefficient $(\rho)=0.349$ ).

The results of DC/TMD Axis I clinical examination revealed either single diagnosis but mostly combined diagnoses as shown in Table 1. Among 128 patients, 120 patients $(93.75 \%)$ had TMJ disorders that were accompanied by muscle pain disorders. Only 26 patients had TMJ disorders that were not accompanied by any

Table 2. The effect of gender and age variables on TMJ and muscle pain disorders

\begin{tabular}{|c|c|c|c|c|c|}
\hline TMJ Disorders & $\begin{array}{l}\text { Female } \\
\text { n (\%) }\end{array}$ & $\begin{array}{l}\text { Male } \\
\text { n (\%) }\end{array}$ & $\begin{array}{l}18-32 \text { years } \\
n(\%)\end{array}$ & $\begin{array}{l}33-50 \text { years } \\
n(\%)\end{array}$ & $\begin{array}{l}\text { Total } \\
\text { n (\%) }\end{array}$ \\
\hline DDwR & $43(33.6 \%)$ & $25(19.5 \%)$ & 37 (28.9\%) & $31(24.2 \%)$ & $68(53.1 \%)$ \\
\hline DdwRwlL & $9(7.0 \%)$ & $1(0.8 \%)$ & $5(3.9 \%)$ & $5(3.9 \%)$ & $10(7.8 \%)$ \\
\hline DDw/oRwLO & $23(18.0 \%)$ & $6(4.7 \%)$ & $10(7.8 \%)$ & $19(14.8 \%)$ & $29(22.7 \%)$ \\
\hline DDw/oRw/Olo & $3(2.3 \%)$ & $0(0.0 \%)$ & $0(0 \%)$ & $3(2.3 \%)$ & $3(2.3 \%)$ \\
\hline Subluxation & $7(5.5 \%)$ & $3(2.3 \%)$ & $4(3.1 \%)$ & $6(4.7 \%)$ & $10(7.8 \%)$ \\
\hline $\mathrm{DD}$ & $7(5.5 \%)$ & $1(0.8 \%)$ & $3(2.3 \%)$ & $5(3.9 \%)$ & $8(6.3 \%)$ \\
\hline p-value & 0.123 & & 0.263 & & \\
\hline \multicolumn{6}{|c|}{ Muscle Pain Disorders } \\
\hline No muscle pain & $18(14.1 \%)$ & $8(6.3 \%)$ & $13(10.2 \%)$ & $13(10.2 \%)$ & 26 (20.3\%) \\
\hline Myalgia & $29(22.7 \%)$ & $17(13.3 \%)$ & $26(20.3 \%)$ & $20(15.6 \%)$ & $46(36.0 \%)$ \\
\hline $\begin{array}{l}\text { Myofascial pain with } \\
\text { referral }\end{array}$ & $45(35.2 \%)$ & $11(8.6 \%)$ & $20(15.6 \%)$ & $36(28.1 \%)$ & $56(43.8 \%)$ \\
\hline $\mathrm{p}$-value & 0.145 & & 0.100 & & \\
\hline
\end{tabular}

DDwR: Disc displacement with reduction, DDwRwIL: Disc displacement with reduction with intermittent locking,

DDw/oRwLO: Disc displacement without reduction with limited opening,

DDw/oRw/oLO: Disc displacement without reduction without limited opening,

DD: Degenerative diseases 
Table 3. The distribution of the answers [n (\%)] given to the items of Jaw Functional Limitation Scale-8 (JFLS-8)

\begin{tabular}{lllll}
\hline Items & Responses & & & \\
& 0 & $1-3$ & $4-6$ & $7-10$ \\
\hline 1. Chewing though food & $3(2.3 \%)$ & $21(16.4 \%)$ & $40(31.3 \%)$ & $64(50.0 \%)$ \\
\hline $\begin{array}{l}\text { 2. Chewing chicken } \\
\text { (e.g. prepared in oven) }\end{array}$ & $10(7.8 \%)$ & $29(22.7 \%)$ & $43(33.6 \%)$ & $46(35.9 \%)$ \\
\hline $\begin{array}{l}\text { 3. Eating soft food } \\
\text { requiring no chewing }\end{array}$ & $57(44.5 \%)$ & $37(28.9 \%)$ & $25(19.5 \%)$ & $9(7 \%)$ \\
$\begin{array}{l}\text { 4. Opening wide enough } \\
\text { to drink from a cup }\end{array}$ & $48(37.5 \%)$ & $32(25.0 \%)$ & $27(21.1 \%)$ & $21(16.4 \%)$ \\
$\begin{array}{l}\text { 5. Swallowing } \\
\text { 6. Yawning }\end{array}$ & $59(46.1 \%)$ & $39(30.5 \%)$ & $19(14.8 \%)$ & $11(8.6 \%)$ \\
\hline 7. Talking & $5(3.9 \%)$ & $16(12.5 \%)$ & $21(16.4 \%)$ & $86(67.2 \%)$ \\
\hline 8. Smiling & $29(22.7 \%)$ & $35(27.3 \%)$ & $36(28.1 \%)$ & $28(21.9 \%)$ \\
\hline
\end{tabular}

muscle pain disorders. Myalgia was the most common muscle pain disorder among individuals with disc displacement with reduction (DDwR). Myofascial pain with referral was the most prevalent muscle pain disorders in patients with disc displacement without reduction with limited opening (DDw/oRwLO) and subluxation. Disc displacement with reduction (53.1\%) was the most commonly found TMD, followed by myofascial pain with referral (43.8\%) and myalgia (36\%).

The frequency of different DC/TMD Axis I diagnoses according to gender and age was shown in Table 2. The effect of gender and age on the DC/TMD Axis I diagnoses and presence of disorders were analyzed by Pearson's chi-square tests and it was found to not be statistically significant (TMJ disorders; $p=0.123, p=0.263$; Muscle pain disorder; $p=0.145, p=0.100$; respectively).

Jaw functional limitation scale-8 was used to detect the functional limitation due to the pain-associated TMD. The Cronbach's alpha was found 0.84 for these eight items so, it has showed high reliability (Item 1: Chew though food, Item 2: Chew chicken (e.g. prepared in oven), Item 3: Eat soft food requiring no chewing, Item 4: Open wide enough to drink from a cup, Item 5: Swallow, Item 6: Yawn, Item 7: Talk, Item 8: Smile). According to JFLS-8, the highest score in the limitation of jaw function was obtained during chewing tough food (50\%), yawning $(67.2 \%)$ (Table 3$)$.

In this study, JFLS-8 scoring of TMJ disorders according to DC/TMD was examined (Table 4).Kolmogorov- Smirnov test was used to analyze the normality assumption. Due to non-normally distributed scores, the Kruskal-Wallis test was used for comparing six subgroups of TMJ disorders (DDwR:Disc displacement with reduction; DdwRwlL:Disc displacement with reduction with intermittent locking; DDw/oRwLO:Disc displacement without reduction with limited opening; DDw/oRw/oLO:Disc displacement without reduction without limited opening; Subluxation; DD:Degenerative diseases). Following the Kruskal-Wallis test, the Bonferroni correction for the Mann-Whitney $U$ test was used to detect the specific items differed. A significant difference was observed between DDwR and DDw/oRwLO for the item 1, 2 and 4 of JFLS ( $p=0.001, p=0.004$, $p=0.007, p=0.008$ respectively). Also, there was a significant difference in the comparison of DDwR with 'DDw/ oRw/oLO ( $p=0.006, p=0.008)$ and DDwR withDD' in terms of the item 5 of JFLS $(p=0.005, p=0.008)$.

\section{Discussion}

DC/TMD has dual axis system (Axis I and II). ${ }^{6}$ Diagnosis of common disorders in TMD is determined by Axis I physical examination. Axis II consists of psychosocial and behavioral analysis questionnaires. With Axis II, psychosocial and behavioral factors that affect the patient's response to treatment can be evaluated. ${ }^{6}$ Therefore, we used DC/TMD to determine the frequency of subgroups according to Axis I clinical examination in TMD patient population. Patients mostly exhibited combined diagnoses. Results demonstrated that 26 patients with TMJ disorders had a single diagnosis, which corresponds to $20 \%$ of the patient population. This result is comparable to the results of the study where patients received 33\% TMJ disorders reference DC/TMD diagnosis. ${ }^{10}$

Myalgia was the most common muscle pain disorder accompanying disc displacement with reduction. Myofascial pain with referral was the most prevalent muscle pain disorder in patients with DDw/oRwLO. In a previous study where RDC/TMD diagnoses were evaluated, $64.3 \%$ of patients received RDC/TMD diagnoses of more than one group, which is comparable with our results. ${ }^{11}$

DDwRwas the most frequent Axis I diagnosis, followed by myofascial pain with referral (43.8\%) and myalgia. In the literature, muscle disorders predominate articular disorders. ${ }^{12,13}$ The conflicting results of our study may be related to the lack of heterogeneity of this relatively small patient population. However, comparably lower frequency of muscle disorders has been reported in a study of Asian patients with TMD. ${ }^{14}$ 
Table 4. Comparison of TMJ disorders by JFLS-8 scores

\begin{tabular}{|c|c|c|c|c|c|c|c|c|c|}
\hline \multirow{2}{*}{$\begin{array}{l}\text { JFLS-8 } \\
\text { Items }\end{array}$} & \multicolumn{6}{|c|}{ TMJ Disorders } & \multicolumn{3}{|c|}{ Kruskal Wallis test } \\
\hline & $\begin{array}{l}\text { DDwR } \\
\text { (I) }\end{array}$ & $\begin{array}{l}\text { DdwRwIL } \\
\text { (II) }\end{array}$ & $\begin{array}{l}\text { DDw/oRwLO } \\
\text { (III) }\end{array}$ & $\begin{array}{l}\text { DDw/oRw/oLO } \\
\text { (IV) }\end{array}$ & $\begin{array}{l}\text { Subluxation } \\
\text { (V) }\end{array}$ & $\begin{array}{l}\text { DD } \\
(\mathrm{VI})\end{array}$ & $\chi^{2}$ & p-value & $\begin{array}{l}\text { Bonferroni-corrected } \\
\text { Mann-Whitney U test }\end{array}$ \\
\hline 1 & 5.6176 & 6.5000 & 7.6970 & 6.6667 & 6.8000 & 5.8750 & 12.606 & $0.014^{*}$ & $0.001\left(\mathrm{I}-\mathrm{III} \mathrm{I}^{\star \star}\right)$ \\
\hline 2 & 4.5588 & 4.3333 & 6.4242 & 6.3333 & 6.4000 & 5.8750 & 11.259 & $0.042^{*}$ & $0.004\left(\mathrm{I}-\mathrm{III}^{\star \star}\right)$ \\
\hline 3 & 1.8235 & 0.5000 & 2.3939 & 5.0000 & 2.1000 & 3.3750 & 10.734 & 0.294 & - \\
\hline 4 & 2.1471 & 0.6667 & 4.4242 & 6.3333 & 2.7000 & 3.7500 & 15.885 & $0.001^{*}$ & $0.007\left(I-I I I^{* *}\right)$ \\
\hline 5 & 1.4265 & 1.3333 & 2.4545 & 6.0000 & 4.5000 & 2.8750 & 16.515 & $0.014^{*}$ & $\begin{array}{l}0.006\left(\mathrm{I}-\mathrm{IV}{ }^{\star \star}\right) \\
0.024(\mathrm{II}-\mathrm{IV}) \\
0.005\left(\mathrm{I}-\mathrm{V} \mathrm{I}^{\star \star}\right) \\
0.019(\mathrm{I}-\mathrm{V})\end{array}$ \\
\hline 6 & 6.4412 & 7.6667 & 7.7273 & 8.0000 & 7.6000 & 7.0000 & 10.528 & 0.062 & - \\
\hline 7 & 3.3382 & 3.1667 & 4.9394 & 2.0000 & 5.2000 & 4.2500 & 8.291 & 0.141 & - \\
\hline 8 & 2.8971 & 3.5000 & 4.6970 & 2.3333 & 4.8000 & 3.8750 & 8.382 & 0.263 & - \\
\hline
\end{tabular}

DDwR: Disc displacement with reduction, DDwRwIL: Disc displacement with reduction with intermittent locking,

DDw/oRwLO: Disc displacement without reduction with limited opening, DDw/oRw/oLO: Disc displacement without reduction without limited opening,

DD: Degenerative diseases; *significant at the 0.05 level (Kruskal Wallis test), ${ }^{* *}$ significant at the 0.008 level (Bonferroni-corrected Mann-Whitney U test)

Demographic evaluation of the TMD patient population showed that the prevalence of TMD in female patients was almost three times more common than in males. TMD is mostly seen in females because of hormonal, postural, emotional, and functional factors, in addition to the muscular structure and genetic predisposition. ${ }^{15-18}$ Similarly, the result of the present study indicates that the female gender is an important factor in the etiology of TMD. Prevalence of headaches including the temple areas of the head in the last 30 days was also significantly higher in females.

The frequency and severity of signs and symptoms of TMD increase between the second and forth decades of life and are more common in females than males. ${ }^{19}$ Han and Harrison ${ }^{20}$ reported that $30 \%$ of females between the ages of 20-40 have myofacial pain. On the other hand, Velly et al. ${ }^{21}$ reported that age is not related with myofacial pain. Similarly, in our study, the effect of age on muscle pain disorders was not significant.

Regarding pain, $90.6 \%$ of patients reported intermittent or continuous pain in the last 30 days. Pain is the chief complaint in TMD in which patients seek treatment. Pain is found to be aggravated mostly by activities like talking, kissing, yawning. Presence of TMD was found to be significantly associated with oral functional limitation. Today, the TMD Pain Screener can perform routine detection of pain-related TMD. It is a quick and simple method. According to the results of the TMD Pain Screener, the patient can be informed about the pathology and the dentist can take the appropriate precautions to reduce the risk of TMD, in order to keep the procedures as short as possible and to support the patient's jaw during treatment.

DC/TMD Axis II instruments allow the evaluation of patients' psychosocial and behavioral status. JFLS, one of the Axis II instruments, helps to assess limitations in mastication (item 1-3), jaw mobility (item 4), verbal and emotional expressions (item 5-8).

The items in this scale include daily activities in everyday life and determine the symptom's severity and the limitations of the jaw's movement. In patients with DDw/oRwLO, the functional limitation in the item 1, 2 and 4 of the JFLS-8 was scored higher when compared to the patients with DDwR. Based on this result, the limitation in mastication and mobility were major problems in these patients. On the other hand, in patients with DDw/oRw/oLOand DD, the functional limitation in item 5, which defines the restriction on verbal and emotional communication, was scored higher compared to patients with DDwR. According to these results, different functional limitations with a wide range of degrees can be observed in each TMJ subgroups. The limitation of this study was related to the small sample size. In order to generalize and confirm these results, studies involving more participants are required.

\section{Conclusion}

The findings of this study show that DC/TMD is a diagnostic and useful method for identifying pain-related TMD patients. It can be used as an adjunct and additional tool for clinical and research purposes in the diagnosis of temporomandibular disorders with the evaluation criteria in Axis I and II.

\section{ACKNOWLEDGEMENT}

This study was presented as a poster presentation at the $24^{\text {th }}$ TAOMS International Scientific Congress, May 23-27, 2017, Muğla, Turkey 


\section{REFERENCES}

1. Svensson P. Muscle pain in the head: overlap between temporomandibular disorders and tension-type headaches. Curr Opin Neurol 2007;20:320-5.

2. Conti PC, Costa YM, Gonçalves DA, Svensson P. Headaches and myofascial temporomandibular disorders: overlapping entities, separate managements? J Oral Rehabil 2016;43:702-15

3. Tuz HH, Onder EM, Kisnisci RS. Prevalence of otologic complaints in patients with temporomandibular disorder. Am J Orthod Dentofacial Orthop 2003;123:620-3.

4. Goldstein $\mathrm{BH}$. Temporomandibular disorders: a review of current understanding. Oral Surg Oral Med Oral Pathol Oral Radiol Endod 1999;88:379-85.

5. Schiffman E, Ohrbach R, Truelove EL, Look J, Anderson G, Goulet JP, et al. Diagnostic criteria for temporomandibular disorders (DC/ TMD) for clinical and research applications: recommendations of the International RDC/TMD Consortium Network and Orofacial Pain Special Interest Group. J Oral Facial Pain Headache 2014;28:6-27.

6. Schiffman E, Ohrbach R. Executive summary of the Diagnostic Criteria for Temporomandibular Disorders for clinical and research applications. J Am Dent Assoc 2016;147:438-45.

7. Gonzalez YM, Schiffman E, Gordon SM, Seago B, Truelove EL, Slade $\mathrm{G}$, et al. Development of a brief and effective temporomandibular disorder pain screening questionnaire: reliability and validity. J Am Dent Assoc 2011;142:1183-91.

8. Ohrbach R, Granger C, List T, Dworkin S. Preliminary development and validation of the Jaw Functional Limitation Scale. Community Dent Oral Epidemiol 2008;36:228-36.

9. Ohrbach R, Larsson P, List T. The Jaw Functional Limitation Scale: development, reliability, and validity of 8 -item and 20 -item versions. J Orofac Pain 2008;22:219-30.

10. Lövgren A, Parvaneh H, Lobbezoo F, Häggman-Henrikson B, Wänman $A$, Visscher CM. Diagnostic accuracy of three screening questions $(3 Q / T M D)$ in relation to the $D C / T M D$ in a specialized orofacial pain clinic. Acta Odontol Scand 2018;76:380-6.

11. Manfredini D, Piccotti F, Ferronato G, Guarda-Nardini L. Age peaks of different RDC/TMD diagnoses in a patient population. J Dent 2010;38:392-9

12. Winocur E, Steinkeller-Dekel M, Reiter S, Eli I. A retrospective analysis of temporomandibular findings among Israeli born patients based on the RDC/TMD. J Oral Rehabil 2009;36:11-7.

13. Manfredini D, Segù $M$, Bertacci $A$, Binotti $G$, Bosco $M$. Diagnosis of temporomandibular disorders according to RDC/TMD axis I findings, a multicenter Italian study. Minerva Stomatol 2004;53:429-38.

14. Yap AU, Dworkin SF, Chua EK, List T, Tan KB, Prosthodont C, et al. Prevalence of temporomandibular disorder subtypes, psychologic distress, and psychosocial dysfunction in Asian patients. J Orofac Pain 2003;17:21-8.

15. Ciancaglini R, Gherlone EF, Redaelli S, Radaelli G. The distribution of occlusal contacts in the intercuspal position and temporomandibular disorder. J Oral Rehabil 2002;29:1082-90.

16. Kafas $P$, Leeson R. Assessment of pain in temporomandibular disorders: the bio-psychosocial complexity. Int J Oral Maxillofac Surg 2006;35:145-9.

17. Magnusson T, Egermark I, Carlsson GE. A longitudinal epidemiologic study of signs and symptoms of temporomandibular disorders from 15 to 35 years of age. J Orofac Pain 2000;14:310-19.

18. Pedroni CR, De Oliveira AS, Guaratini MI. Prevalence study of signs and symptoms of temporomandibular disorders in university students. J Oral Rehabil 2003;30:283-9.

19. Okeson JP. Orofacial pain: Guidelines for assessment diagnosis and management. 1st ed. Illinois: Quintessence Publishing; 1996.

20. Han SC, Harrison P. Myofascial pain syndrome and trigger-point. Reg Anesth Pain Med 1997;22:89-101.

21. Velly AM, Gornitsky M, Philippe P. Contributing factors to chronic myofascial pain: a case-control study. Pain 2003;104:491-9.

\section{Temporomandibular düzensizlik tanı kriterlerini kullanarak temporomandibular bozukluğu olan hastaların klinik değerlendirilmesi ve sınıflandırıması}

\section{Özet}

AmAÇ: Bu çalışmanın amacı, 'temporomandibular düzensizlikler için teşhis kriterlerini (DC-TMD)' kullanarak, temporomandibular düzensizlik şikâyeti olan hastalarda klinikte alt grupların dağılım sıklığını değerlendirmektir.

GeREÇ VE YönTEM: Çalışmaya, temporomandibular düzensizlik (TMD) şikâyeti olan 128 hasta (92 kadın ve 36 erkek, yaş ortalaması $33.5 \pm 8.28$ ) dahil edildi. DC/TMD Eksen I tanı kriterleri ile ağıı bozuklukları ve temporomandibular eklem (TME) düzensizliklerinin dağılımı incelendi. DC/TMD Eksen l'de yer alan TMD Ağrı anketi (TMD Pain Screener) ile de son $\mathbf{3 0}$ gün boyunca mevcut ağrının incelemesi yapılmıştır. Semptomların şiddetini ve fonksiyon kısıtlııı̆ını belirlemek için DC/TMD Eksen II değerlendirme araçlarından biri olan 'Çene Fonksiyon Kısıtlanma Skalası-8 (JFLS-8)' tercih edilmiştir. Verilerin analizi Ki-kare, Kruskal Wallis testi ve Bonferroni düzeltmeli Mann-Whitney $U$ testi kullanılarak yapılmıştır.

BULGULAR: Çalışmada 128 hastanın 120'sinde (\%93.75) kas ağrı bozukluğuna eşlik eden TME düzensizliği vardı. Cinsiyet ve yaşın, TME/kas ağrı bozuklukları üzerine etkisi anlamlı değildir (sırasıyla, TME düzensizliği $p=0.123$, $p=0.263$; kas ağrı bozukluğu $p=0.145, p=0.100$ ). JFLS-8'e göre, diğer gruplarla karşılaştırıldığında 'kısıtlı ağız açıklığı olan redüksiyonsuz disk deplasmanı' grubunda, çiğnemede zorluk ( 1 ve 2 . maddeler) ve eklem hareketinde kısıtlılık (4. madde) majör şikayetler olarak bulunmuştur ( $p=0.001, p=0.004, p=0.007, p<0.008)$.

SonUÇ: DC/TMD Eksen I, TMD tanısı ve değerlendirilmesinde klinisyenler için önemli bir referans olup, DC/TMD Eksen II'de JFLS-8, TMD'ye bağlı çene fonksiyon kısıtılığın tespitinde etkin bir değerlendirme aracıdır.

Anahtar Kelimeler: Temporomandibular eklem bozuklukları; temporomandibular eklem disfonksiyon sendromu; temporomandibular eklem disk 